Science, Technology and Development 35 (1): 22-25, 2016

ISSN 0254-6418 / DOI: 10.3923/std.2016.22.25

(C) 2016 Pakistan Council for Science and Technology

\title{
Preliminary Investigations for the Upgradation of North Waziristan Manganese Ore
}

\author{
Ishaq Ahmad \\ Department of Mining Engineering, University of Engineering and Technology, \\ Peshawar, 25120, Pakistan
}

\begin{abstract}
Manganese is very important alloying element for the production of steel and many other products. It is found in various parts of Khyber Pakhtunkhwa (KP) province and North Waziristan (NW) agency areas of Pakistan. Manganese deposits of NW are of low-grade and need processing to make the mineral mineable and profitable. Mineralogical investigation is carried out for the determination of ore and gangue minerals; fractioning and chemical analysis are conducted to measure the average assay (grade) of various minerals and also their distribution in different size fractions. On the basis of mineralogy and chemical investigations, a beneficiation method is selected. On the basis of laboratory investigations, it was found that manganese is the only valuable mineral present, whereas the silica is the main gangue minerals present in the ore. The average grade of manganese in the run-of-mine ore is $12.51 \%$, whereas, the grade of silica in the ore is nearly $50 \%$. The upgradation of the ore was carried out, using gravity concentration technique. The results of upgradation showed that grade of the manganese in the ore increased to $25.9 \%$ with a recovery of $73.54 \%$ and the concentration of silica decreased up to $42.24 \%$.
\end{abstract}

Key words: Mineralogical, chemical, manganese, upgradation, beneficiation, assay, grade, gravity separation, XRD

\section{INTRODUCTION}

In earth's crust, the manganese content is $0.11 \%$, which is the twelfth most abundant element. This concentration is very small as compared to aluminum: 8.2\%; iron: $6.3 \%$ and titanium: $0.66 \%$; but considerably higher than many commercial metals, like, copper: $0.0068 \%$; zinc: $0.0079 \%$ and lead: $0.001 \%$. Manganese has an important contribution for the manufacturing of ferroalloys and steel (Khan et al., 2004). It can also be used for the non-metallurgical purposes, e.g., for the manufacturing of dry cell batteries, animal feed and plant fertilizer (Corathers, 2015) and therefore, has greater importance from industrial point of view.

It has got big demand everywhere in the world. The consumption of manganese in Pakistan can be judged from the fact that millions of rupees per month are spent on the import of manganese from various parts of the world for the production of steel. Its importance can also be determined from the fact that it has no substitute in its applications (Kanungo et al., 2008). Various minerals present in the manganese are pyrolusite $\left(\mathrm{MnO}_{2}\right)$; braunite $\left(\mathrm{Mn}^{2+} \mathrm{Mn}^{3+6}\right)\left(\mathrm{O}_{8}\right)\left(\mathrm{SiO}_{2}\right)$; psilomelane $\left(\mathrm{Ba}, \mathrm{H}_{2} \mathrm{O}\right)_{2} \mathrm{Mn}_{5} \mathrm{O}_{10}$ and rhodochrosite $\left(\mathrm{MnCO}_{3}\right)$. Pyrolusite is the most stable and abundant. It commonly occurs as low temperature hydrothermal deposits (Post, 1999).
In Pakistan, manganese deposits are found in Federally Administered Tribal Areas (FATA) in NW, Kurram and Bajaur Agencies, Chura Gally in Mansehra (KP) and Lasbela (Baluchistan). In NW agency the manganese deposits are found in Saidgi and Shuidar areas which is nearly $26 \mathrm{~km}$ from Miran Shah (NW agency headquarter). The inferred reserves, reported in the Saidgi area, are 34,000 metric tons (Khan, 1998).

Manganese grade is the main parameter, which is responsible for the market value of the ore. There is a need of upgradation of low grade metallic minerals, which are usually associated with gangue minerals. Clay or soil contamination is normally removed by washing the ore, followed by the crushing, grinding and screening of the ore. The other beneficiation methods for the upgradation of manganese are gravity concentration, magnetic separation and froth flotation.

The methods of beneficiating of low grade ores normally depend upon many factors and have been discussed in details by Wills (1997). The factors, influence the selection of a beneficiation technique, are ore mineralogy, chemical composition, density difference between various minerals, surface properties, magnetic and electrostatic properties. Various techniques are available in the literature for the upgradation of manganese ores of various localities of the world 
(Rahman et al., 2008; Bilqees et al., 2014; Chinnaiah, 2014; Mehdilo et al., 2013; Mishra, 2014; Mishra et al., 2009, Mohapatra and Mishra, 2006). As the manganese is heavier, having the density of more than $7000 \mathrm{~kg} \mathrm{~m}^{-3}$, the manganese upgradation techniques based on density or specific gravity could be preferable in case of silica or other lighter minerals associated as gangue impurity. However, if the associated non-valuable mineral in the ore is iron then magnetic separation could be applied. The froth flotation exploiting the surface properties of the minerals could also be a useful in case the ore is ground below 100 micron size, which is comparatively expensive. In the current research work, the manganese ore samples from NW agency were investigated with the aim to determine valuable and gangue minerals present; their assay value (grade) in average and in various size fractions; to find the suitable techniques for the upgradation of manganese, reduction of silica in the ore and to perform the upgradation of the ore, using most appropriate technique selected on the basis of preliminary investigations.

\section{MATERIALS AND METHODS}

Nearly $40 \mathrm{~kg}$ of manganese ore samples from NW area were collected in the mineral processing laboratory of the Department of Mining Engineering, University of Engineering and Technology (UET), Peshawar, Pakistan. Large lumps of the ore were reduced in size manually with the help of hammer to make them suitable for laboratory jaw crusher feed. Nearly $8 \mathrm{~kg}$ ore was crushed in laboratory jaw and roll crushers, which gave the product of $1.2 \mathrm{~cm}$ size. The roll crusher product was again crushed in disc crusher and then in mortar mill, which gave the final product below $2.5 \mathrm{~mm}$ size.

The sample was then coned and quartered to obtain $1 \mathrm{~kg}$ representative samples, which were stored in plastic bags. Mineralogical investigation was carried out on the representative samples at Centralized Resource Laboratory (CRL) of the University of Peshawar by $\mathrm{X}$-Ray diffraction (XRD) to determine the valuable and gangue minerals present in the ore. Ore fractioning was conducted with the help of test sieves. Chemical analysis of various sieve size fractions was carried out at the Mineral Testing Laboratory (MTL) of the Directorate General of Mines and Minerals (DGMM), KP. On the basis of mineralogical and chemical analysis, it was decided to upgrade the ore by gravity separation, using laboratory shaking table.

\section{RESULTS AND DISCUSSION}

Mineralogical analysis: Representative ore samples were investigated to determine the ore and gangue minerals

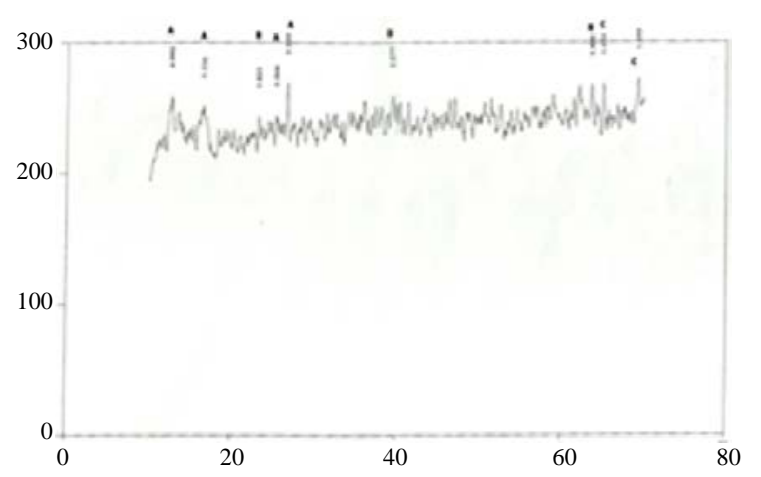

Fig. 1: XRD pattern

\begin{tabular}{lccl}
\multicolumn{4}{l}{ Table 1: XRD analysis of sample } \\
\hline 2 Theta & d-value & Intensity & Mineral code letter \\
\hline 12.65 & 6.992 & 259 & A \\
16.60 & 5.336 & 251 & A \\
23.25 & 3.823 & 243 & A, B \\
25.40 & 3.504 & 244 & A \\
26.75 & 3.330 & 269 & A \\
39.55 & 2.277 & 259 & D \\
63.70 & 1.460 & 267 & B \\
65.05 & 1.433 & 268 & B, C \\
69.30 & 1.355 & 272 & C \\
\hline
\end{tabular}

present. The results of the XRD investigation from CRL are shown in Table 1 and the graph is given in Fig. 1.

The results obtained were confirmed by ASTM card numbers. The letter $\mathrm{A}$ in Table 1 shows the presence of $\mathrm{SiO}_{2} ; \mathrm{B}$ shows $\mathrm{Fe}_{2}+2 \mathrm{SiO}_{4}$; C shows $\mathrm{Mn}_{2} \mathrm{SiO}_{4}$ and $\mathrm{D}$ shows Mn.Si, after comparison with ASTM standards, the presence of manganese was confirmed in the form of silicate. However, silica was also available in free form as $\mathrm{SiO}_{2}$. Traces of iron were also detected in the ore. It was ascertained from the finding of XRD that the manganese is the only ore mineral present, whereas the silica is the major gangue mineral present in the sample with very small amount of iron as well.

Ore fractioning and chemical analysis: A representative sample from the ground ore was fractioned into seven sizes using dry sieving on laboratory sieve shaker. Sieves used for the ore fractioning were 2000, 1200, 450, 300, 250 and $125 \mu \mathrm{m}$. The mass retained after being sieving was weighed and then all the mass fractions obtained were sent to MTL for X-Ray fluorescence (XRF) analysis. The results of fractioning and chemical analysis are shown in Table 2. Column 1 shows the fractions numbering represented with i, Column 2 shows the sieve size fractions in microns, columns 3 and 4 show the mass retained, $m$ on each size fraction in grams and percentage respectively; whereas the columns 5 and 6 show the grade of manganese, $g_{M}$ and grade of silica, $g_{s}$, respectively. 
Sci. Technol. Dev., 35 (1): 22-25, 2016

\begin{tabular}{|c|c|c|c|c|c|}
\hline Fraction number (i) & Sieve size fraction $(\mu \mathrm{m})$ & Mass retained (g) & Mass retained, $\mathrm{m}_{\mathrm{i}}(\%)$ & Manganese grade $\mathrm{g}_{\mathrm{iM}}(\%)$ & Silica grade, $\mathrm{g}_{\mathrm{is}}(\%)$ \\
\hline 1 & +2000 & 45.40 & 2.31 & 1.00 & 46.40 \\
\hline 2 & $-2000+1200$ & 548.20 & 27.85 & 5.00 & 47.50 \\
\hline 3 & $-1200+450$ & 398.20 & 20.23 & 10.50 & 44.00 \\
\hline 4 & $-450+300$ & 363.30 & 18.46 & 24.00 & 43.00 \\
\hline 5 & $-300+250$ & 29.10 & 1.48 & 20.00 & 47.50 \\
\hline 6 & $-250+125$ & 217.10 & 11.03 & 16.50 & 60.30 \\
\hline \multirow[t]{3}{*}{7} & -125 & 366.90 & 18.64 & 13.00 & 61.60 \\
\hline & & \multicolumn{2}{|c|}{ Total mass, $\Sigma \mathrm{m}$} & \multicolumn{2}{|c|}{ Average grade, G (\%) } \\
\hline & & 1968.20 & 100.00 & 12.51 & 49.98 \\
\hline
\end{tabular}

From Table 2, it may be seen that the grade of manganese has a maximum value of $24 \%$ which lies in the size range of $-450+300 \mu \mathrm{m}$ and it is further observed that it gradually decreased above or below this size. Similarly, it was further observed that the silica grade is minimum at this size range, i.e. $43 \%$. From this data it may be concluded that the maximum liberation of manganese mineral could be obtained at this size range, which is the optimum mesh of grind size for the ore.

Average grade of manganese and silica in the sample was determined from the mass and their components distribution using the relation given in Eq. 1:

$$
\mathrm{G}=\frac{\sum_{\mathrm{i}=1}^{7}\left(\mathrm{~m}_{\mathrm{i}} \times \mathrm{g}_{\mathrm{i}}\right)}{\sum_{\mathrm{i}=1}^{7} \mathrm{~m}_{\mathrm{i}}}
$$

The results show that the average grade of manganese, $\mathrm{g}_{\mathrm{M}}$ in the ore is $12.51 \%$ whereas the average grade of silica, $g_{s}$ is nearly $50 \%$. The grade determined, in this way, is more reliable and representative because it is taken as the average from seven different size fractions and it also considers the distribution of mass in each size fraction. A carefully prepared sample was also chemically analyzed to determine the grade of iron in the ore which was found only $7 \%$.

Method selection and upgradation: As the ore (manganese) minerals are heavier, having specific gravity (SG) 7.32 and gangue (silica) are lighter, having SG 2.65, the value of Concentration Criterion (CC) for the selection of gravity separation process can be obtained, using the relation given in Eq. 2 (Gupta and Yan, 2006):

$$
\mathrm{CC}=\frac{\mathrm{SG} \text { of heavy minerals }-\mathrm{SG} \text { of fluid }}{\mathrm{SG} \text { of lighter minerals }-\mathrm{SG} \text { of fluid }}
$$

The Specific Gravity (SG) of water (fluid) is taken as 1.00. The value of CC obtained is 3.83 and this value is sufficient for the selection of gravity separation technique for the ore under investigation.
Gravity concentration studies were performed on ground manganese ore, using shaking table. Four products were obtained from shaking table tests, i.e., concentrate 1 , concentrate 2 , middling and tailings fractions. After combining the concentrate and middling products, it was shown that the grade of manganese was increased from 12.51-25.9\% with an overall recovery of $73.54 \%$. Moreover, it was found that the grade of silica was reduced to $42.24 \%$ in the final concentrate.

\section{CONCLUSION}

Preliminary investigations of manganese ore of NW agency showed that the manganese is the only ore mineral present whereas the silica in the major gangue mineral present in the ore. On the basis of ore fractioning and chemical analysis of various size fractions, it was found that the average grade of manganese and silica in the ore is 12.51 and $50 \%$, respectively. As the density difference between the manganese and silica is large enough for the gravity separation, therefore, the ore was upgraded, using the shaking table technique. The manganese content was upgraded to nearly $26 \%$ with a recovery of nearly $74 \%$. As the optimum mesh of grind size for the manganese ore is $-450+350 \mu \mathrm{m}$, further upgradation studies on this particular size range could result in further increase in the manganese grade. Magnetic separation could be useful to reduce the iron content in the ore.

The author is thankful to MTL, DGMM for conducting chemical analysis of the ore samples.

\section{REFERENCES}

Bilqees, R., F. Haqqani and F. Khan, 2014. Mineralogical characterization and evaluation of manganese ore from Bajaur Agency, Khyber Pakhtunkwa, Pakistan. J. Himalayan Earth Sci., 47: 1-8.

Chinnaiah, 2014. Beneficiation studies of manganese ore of Kumsi, Shimoga, Southern India. Indian J. Appl. Res., 4: 16-18. 
Corathers, L.A., 2015. Mineral commodity summaries 2015. U.S. Department of Interior, U.S. Geological Survey, pp: 100-101.http://minerals.usgs.gov/ minerals/pubs/mcs/2015/mcs2015.pdf.

Gupta, A. and D.S. Yan, 2006. Mineral Processing Design and Operation: An Introduction. 1st Edn., Elsevier, USA., ISBN: 9780080454610, pp: 494.

Kanungo, D.R., G.S. Bisen and B.D. Malpe, 2008. Manganese ore industry in India-a perspective. J. Mines Metals Fuels, 56: 233-239.

Khan, A., 1998. Mineralogy, petrology and geochemistry of manganese mineralization and associated rocks in Saidgi and Shuidar areas, North Waziristan. M.Phil Thesis, NCE in Geology, University of Peshawar, Pakistan.

Khan, A., M.T. Shah, L. Ali and W. Mohammad, 2004. Beneficiation study of the manganese ores of the Saidgi area, North Waziristan Agency, Pakistan. Geol. Bull. Univ. Peshawar, 37: 191-197.

Mehdilo, A., M. Irannajad and M.R. Hojjati-Rad, 2013. Characterization and beneficiation of Iranian low-grade manganese ore. Physicochem. Problems Mineral Process., 49: 725-741.
Mishra, P., 2014. Beneficiation of low grade aluminous Mn-ore from Bonai-Keonjhar belt, Odisha, India. J. Geosci. Geomatics, 2: 12-15.

Mishra, P.P., B.K. Mohapatra and K. Mahanta, 2009. Upgradation of low-grade siliceous manganese ore from Bonai-Keonjhar Belt, Orissa, India. J. Minerals Mater. Characterization Eng., 8: 47-56.

Mohapatra, B.K. and P.P. Mishra, 2006. Influence of fabric on up gradation of low-grade manganese ores from Bonai-Keonjhar belt, Orissa. Proceedings of the International Seminar on Mineral Processing Technology, March 8-10, 2006, Chennai, India, pp: 338.

Post, J.E., 1999. Manganese oxide minerals: Crystal structures and economic and environmental significance. Proc. Nat. Acad. Sci. USA., 96: 3447-3454.

Rahman, M.U., S.A. Kayani, M.Z. Ul Haq and S. Gul, 2008. Biorecovery of manganese from pyrolusite ore using Aspergillus niger PCSIR-06. J. Chem. Soc. Pak., 30: 203-208.

Wills, B.A., 1997. Mineral Processing Technology. 5th Edn., Butterworth Heinemann, Great Britain, UK. 